\title{
BIOCHEMICAL COMPOSITION OF SPRING BARLEY GRAIN PEARLED TO VARYING DEGREES
}

\author{
Māra Bleidere ${ }^{1, \#}$, Zaiga Jansone ${ }^{1}$, Ilze Grunte ${ }^{1}$, and Ida Jakobsone ${ }^{2}$ \\ ${ }^{1}$ Stende Research Centre, Institute of Agricultural Resources and Economics, Dižstende, LV-3258, LATVIA \\ ${ }^{2}$ Food Chemistry Centre, Department of Chemistry, University of Latvia, Riga, LV-1013, LATVIA \\ \# Corresponding author, mara.bleidere@arei.lv
}

Communicated by Zinta Gaile

\begin{abstract}
Differences in biochemical composition in dehulled and pearled grain samples affected by the various degrees of pearling were studied for spring barley (Hordeum vulgare L.). Twelve covered spring barley and two hulless genotypes were examined. Commercial samples of pearled barley were included for comparison. Covered barley grain samples were pearled using a small-scale barley pearler to obtain dehulled and pearled barley grain products with pearling percentage of $12 \%$ and $30 \%$, respectively. Significant differences were observed in the chemical composition between dehulled grain and pearled grain. As the outer layers of the covered grain were removed to a greater degree by pearling, crude protein content, crude ash, total phenolic concentration and radical scavenging activity in the pearled grain significantly decreased $(\mathrm{p}<0.001)$, while starch concentration increased, without changes in the $\beta$-glucans concentration. The concentration of phenolic compounds in the dehulled barley grain samples were 1.30 to 1.61 times higher than for pearled grains. There was a significant $(\mathrm{p}<0.01)$ correlation determined among values of dehulled and pearled grain of different barley genotypes in crude protein, starch, and $\beta$-glucan content, but no relationship was found in total phenolic content and radical scavenging activity.
\end{abstract}

Key words: spring barley, wholegrain, pearled barley, chemical composition.

\section{INTRODUCTION}

Genetic diversity found in barley (Hordeum vulgare L.) provides wide opportunities to identify and create barley varieties for different end uses. Barley has little use for human food in Europe, but is widely used for this purpose in Asia. In the developed countries, the predominant use of barley for human food is the production of beer from malted grain. In developing countries, however, a considerable amount of the grain is used as a cereal and for bread making. The interest in the use of barley in other industrial food applications besides malting has recently grown as barley has the potential to be used as an alternative to the more commonly used cereals (Baik and Ulrich, 2008). However, due to the low use rate of barley in the food industry, there are no generally accepted requirements for food barley, except for the limits of the prevalence of fungal toxins and other antinutritive compounds (Anonymous, 2006). Nevertheless, the physical and chemical characteristics of barley are an important aspect to be considered to reinstate barley as a human food. Therefore, barley breeders continue to breed for these traits as well as investigate new ones that could be beneficial, particularly in term of health benefits for humans.
Barley grain provides low fat, highly digestible carbohydrates (mainly starch) for energy, relatively well-balanced protein to meet amino acid requirements, and insoluble and soluble fibre with general and specific health benefits (Baik, 2014). The health claims are mainly based on the capacity of barley foods to positively affect serum cholesterol and glucose levels, which in turn affect cardio-vascular health and diabetes control (Ames and Rhymer, 2008) due to $\beta$-glucan, a soluble dietary fibre located in the subaleurone layers, endosperm adjacent to the subaleurone layers, and throughout the endosperm (Izydorczyk and Dexter, 2008). There are various possibilities of $\beta$-glucans exploitation as functional ingredients in food, cosmetics, and pharmaceutical industries and as food additives also on the basis of barley $\beta$-glucans (Havrlentova et al., 2011). The interest for the role of natural antioxidant compounds in human health has been increasing during the last few years. Barley grains in general contain different types of phytochemicals, and in barley the most investigated compounds are sterols, tocopherols, tocotrienols, and phenolic compounds and antioxidant activity (Newman and Newman, 2008).

Barley must undergo various processing steps before human consumption, which greatly affect their composition and 
physicochemical properties (Sharma and Kotari, 2016). These properties play an important role in the development of new products. Most barley is what is called "covered barley". One processing method is pearling, a common commercial process whereby the inedible outer hulls are removed and kernels become polished. Minimally processed grains such as dehulled barley is the whole grain form of barley because only the tough inedible outer hull has been removed. When during the pearling process part of the outer bran and embryo is left on the grain, it is known as lightly pearled or pot barley. Removing all the aleurone and embryo produces pearl barley, which is heavily pearled barley (Baik, 2014). A specific type of barley such as hulless barley has an outer hull that is so loosely attached to the kernel that it generally falls off during harvesting. The grains of hull-less barley may also be pearled further, if the removal of bran layers is desired (Baik and Ullrich, 2008). Wholegrain and pearled barley may be processed further by flaking, dry roasting, puffing or milling, for producing different bakery/food products, for example, breads, pasta, or meal components such as barley rice, or for healthy snacks, cookies and other specific barley products with high content of barley beta-glucan (Baik, 2014).

Currently in Latvia the leading grain processing companies are using only the covered type of barley to obtain the barley end-products. Commercially available barley products in Latvia are pot barley, grits, flakes, and flour. Milling companies remove up to $50 \%$ of the barley kernel in the abrasion process, in Latvia it is about 30\% of the barley kernel. The degree of pearling depends on the end-use of the pearled product, but the quality of the initial barley grain is also important. The concentration of crude protein, starch, crude ash, $\beta$-glucans, and total phenolics, and the antiradical activity, were determined in spring barley to identify differences in chemical composition of dehulled and pearled grain products affected by the various degrees of pearling.

\section{MATERIALS AND METHODS}

The following two-row covered spring barley genotypes were used: five promising lines from the Latvian spring barley breeding programme (ST-12902, ST-13083, ST-13074, ST-12924, ST-12835); four commercial barley varieties 'Quench' (Germany), 'Ansis', 'Abava', and 'Jumara' (all Latvian) from the Latvian Catalogue of Plant Varieties; barley accessions 'Grimmet' (Australia), 'Landsorte aus Tirol' (Austria) with high crude protein and $\beta$-glucan concentration (Bleidere and Grunte, 2008) and breeding line 'G-83' with black seed coat colour. The genotypes were examined from perspective of grain chemical composition of dehulled grain and pearled barley grain. Two hulless barley varieties, 'Irbe', and 'Kornelija' (Latvia) as whole grain and a commercial sample of pearled barley (CPB) produced by the grain processing factory "Dobeles Dzirnavnieks" were included for comparison. Barley genotypes were grown at similar conditions and grain samples were obtained from the harvest of 2015. Field trials were established at the Stende Research Centre, Institute of Agricultural Resources and Economics (latitude $57.1412^{\circ} \mathrm{N}$, longitude $22.5367^{\circ}$ E). The soil was Eutric Albeluvisols sandy loam, organic substance concentration $22 \mathrm{~g} \cdot \mathrm{kg}^{-1}$, soil pH KCL 5.9, and available phosphorus $\mathrm{P}_{2} \mathrm{O}_{5} 140 \mathrm{mg} \cdot \mathrm{kg}^{-1}$, and potassium $\mathrm{K}_{2} \mathrm{O} 204 \mathrm{mg} \cdot \mathrm{kg}^{-1}$. In the field experiment a complex mineral fertiliser NPK 16:16:16 was used at the rate $550 \mathrm{~kg} \cdot \mathrm{ha}^{-1}$ (pure matter $\mathrm{N}-80 \mathrm{~kg} \cdot \mathrm{ha}^{-1}, \mathrm{P}_{2} \mathrm{O}_{5}-80 \mathrm{~kg} \cdot \mathrm{ha}^{-1}, \mathrm{~K}_{2} \mathrm{O}-80$ $\left.\mathrm{kg} \cdot \mathrm{ha}^{-1}\right)$.

Grain sizes and pearling conditions were based on conditions used in a Latvian commercial pearling operation of "Dobeles Dzirnavnieks". Covered barley grain polishing or pearling was performed by using a small-scale barley pearler (Dimo's Labtronics) using a No. 30 grit stone. Barley samples (50 g in triplicate) over a $2.2 \mathrm{~mm}$ screen was used for pearling to varying degrees to obtain two types of barley products: dehulled and pearled grain. Barley grains were pearled for 0.33 min to reach extraction percentage of $12 \%$ by weight of the original kernel by removing only the hull to obtain dehulled barley or whole grain samples of covered barley. Grain was pearled for 1.4 min to reach extraction percentage of $30 \%$ by weight of the original kernel to obtain the pearled grain fraction. The required pearling time was adjusted based on the optimum for barley variety 'Ansis' (Latvia).

Chemical properties of barley samples were determined in two replicates. An acceptable maximum difference among duplicate results was $0.2 \%$ for crude protein, starch and crude ash. Grain samples were ground using a Knifetec 1095 Mill (Foss). Sample weights were calculated on a dry weight basis. Crude protein concentration was determined by Kjeldahl method (LVS 277). A nitrogen to protein conversion factor of 6.25 was used. Starch was analysed by the Evers polarimetric method (ISO 10520), and crude ash by dry ashing procedure at $550{ }^{\circ} \mathrm{C}$ (LVS 276:2000).

The total phenolic concentration (TPC) and 2.2-diphenyl1-picrylhydrazyl (DPPH) antiradical scavenging activity (RSA) assay were determined according to a method described in the literature (Ragaee et al., 2006) with some modifications. For the determination of TPC and for RSA, $1.5 \mathrm{~g}$ of grain flour was placed in a Erlenmeyer flask (250 $\mathrm{mL}$ ) and mixed with $30 \mathrm{ml}$ of $50 \%$ (vol.) ethanol. The mixture was stirred at $40{ }^{\circ} \mathrm{C}$ for $15 \mathrm{~min}$ and then at room temperature for $1 \mathrm{~h}$. After extraction, the supernatant was filtered through a filter paper. The filtrate was used for the analysis of TPC and RSA.

The TPC determination method was based on reduction of the Folin-Ciocalteu reagent by phenols to a mixture of reaction products, and measurement at absorbance maximum $765 \mathrm{~nm}$. One millilitre of extract was mixed with $5 \mathrm{ml}$ of $10 \%$ Folin-Ciocalteu's reagent in distilled water and $4 \mathrm{~mL}$ $7.5 \% \mathrm{Na}_{2} \mathrm{CO}_{3}$ solution, stirred for $30 \mathrm{~min}$ at room temperature and the absorbance at $765 \mathrm{~nm}$ was measured using a spectrophotometer UVIKON 930 (Kontron Instruments, Italy). TPC was calculated using gallic acid as a standard and expressed as mg gallic acid equivalents (GAE) per $100 \mathrm{~g}$ of grain dry weight (DW). 
In RSA assay, $0.4 \mathrm{~mL}$ extract (sample) or $50 \%$ (vol.) ethanol (control sample) was added to $3.6 \mathrm{ml}$ of $10^{-4} \mathrm{M} \mathrm{DPPH}$ solution in ethanol and mixed. The mixture was vigorously shaken and left to stand for $20 \mathrm{~min}$. The absorbance at 517 $\mathrm{nm}$ was measured against $50 \%$ (vol.) ethanol as a blank. The DPPH radical scavenging activity (\%) was calculated using equation (1):

$A R A, \%=\frac{A_{\text {control }}-A_{\text {sample }}}{A_{\text {control }}} \times 100$, where

$A_{\text {control }}$ is the absorbance of the control sample; $A_{\text {sample }}$ is the absorbance of the sample.

Significant differences among trait means of different pearling fractions were tested by the t-test paired two samples for means. Simple correlations (Pearson correlation) were determined and regression analysis was also conducted.

\section{RESULTS}

Crude protein concentration in the dehulled covered barley grain varied from 89.9 to $149.9 \mathrm{~g} \cdot \mathrm{kg}^{-1}$, and in the pearled grain from 84 to $140.7 \mathrm{~g} \mathrm{~kg}^{-1}$ (Table 1). The difference in crude protein concentration between these grain fractions was significant $(p<0.001)$, where pearling decreased average crude protein concentration by $8.6 \mathrm{~g} \cdot \mathrm{kg}^{-1}$ or $7.7 \%$.

The correlation coefficient determined between crude protein concentration in dehulled and pearled barley samples was high and significant $r=0.985(p<0.01)$. This indicates the potential to produce high-protein pearled barley product using covered barley grain characterised by high protein concentration.

This relationship was also high and significant when varieties 'Grimmet', 'Ladsorte aus Tirol' and breeding line 'G-83' with high crude protein concentration were excluded from the dataset $r=0.878(p<0.01)$. Only these genotypes showed higher crude protein concentration in the pearled product than in the commercial sample of pearled barley. Crude protein concentration in grain for unprocessed hulless barley varieties 'Irbe' and 'Kornelija' were variable and higher than in most dehulled grains of covered barley genotypes.

The difference of crude protein concentration among dehulled and pearled grain samples was from $2.7 \mathrm{~g} \cdot \mathrm{kg}^{-1}$ for barley variety 'Landsorte aus Tirol' to $18.5 \mathrm{~g} \cdot \mathrm{kg}^{-1}$ for barley variety 'Abava'.

Rather high variation was observed also in starch concentration in the analysed grain fractions (Table 1). As the outer layers of the grain were removed by pearling, the starch concentration in the pearled grain increased. The increase of average starch concentration in pearled grain (by $46.3 \mathrm{~g} \cdot \mathrm{kg}^{-1}$ or $\left.6.8 \%\right)$ was statistically significant $(p<$ 0.001). The correlation coefficient of starch concentration between dehulled and pearled covered barley grain was high and significant $\mathrm{r}=0.960(p<0.01)$.
Table 1

CRUDE PROTEIN AND STARCH CONCENTRATION IN DEHULLED, PEARLED AND HULLESS BARLEY GRAIN

\begin{tabular}{|c|c|c|c|c|c|c|}
\hline \multirow[b]{2}{*}{ Accessions } & \multicolumn{3}{|c|}{ Crude protein, $\mathrm{g} \cdot \mathrm{kg}^{-1}$} & \multicolumn{3}{|c|}{ Starch, $\mathrm{g} \cdot \mathrm{kg}^{-1}$} \\
\hline & $\begin{array}{c}\text { dehulled } \\
\text { grain }\end{array}$ & $\begin{array}{c}\text { pearled } \\
\text { grain }\end{array}$ & $\begin{array}{l}\text { differ- } \\
\text { ence }\end{array}$ & $\begin{array}{c}\text { dehulled } \\
\text { grain }\end{array}$ & $\begin{array}{c}\text { pearled } \\
\text { grain }\end{array}$ & $\begin{array}{l}\text { differ- } \\
\text { ence }\end{array}$ \\
\hline \multicolumn{7}{|c|}{ Covered barley } \\
\hline ST-12902 & 89.9 & 84.2 & -5.7 & 689.3 & 734.5 & 45.2 \\
\hline ST-13083 & 94.9 & 86.9 & -8.0 & 696.3 & 751.7 & 55.4 \\
\hline ST-13074 & 98.4 & 90.4 & -8.0 & 705.5 & 745.7 & 40.2 \\
\hline ST-12924 & 98.7 & 91.4 & -7.3 & 706.0 & 745.3 & 39.3 \\
\hline ST-12835 & 95.9 & 87.2 & -8.7 & 693.7 & 738.2 & 44.5 \\
\hline Quench & 97.3 & 85.6 & -11.7 & 692.1 & 731.6 & 39.5 \\
\hline Abava & 112.4 & 93.9 & -18.5 & 657.0 & 722.4 & 65.4 \\
\hline Jumara & 102.2 & 95.2 & -7.0 & 678.3 & 723.3 & 45.0 \\
\hline Ansis & 114.0 & 105.9 & -8.1 & 687.3 & 725.6 & 38.3 \\
\hline Grimmet & 142.5 & 134.5 & -8.0 & 633.7 & 683.2 & 49.5 \\
\hline $\begin{array}{l}\text { Landsorte aus } \\
\text { Tirol }\end{array}$ & 141.4 & 138.7 & -2.7 & 645.0 & 682.0 & 37.0 \\
\hline $\mathrm{G}-83$ & 149.9 & 140.7 & -9.2 & 610.0 & 665.5 & 55.5 \\
\hline Average & 111.5a* & $102.9 b$ & -8.6 & $674.5 \mathrm{~b}$ & $720.8 \mathrm{a}$ & 46.3 \\
\hline $\mathrm{CPB} * *$ & $x$ & 108.1 & $x$ & $x$ & 714.0 & $x$ \\
\hline \multicolumn{7}{|c|}{ Hulless barley } \\
\hline Irbe & 121.1 & $x$ & $x$ & 633.8 & $x$ & $x$ \\
\hline Kornelija & 147.3 & $x$ & $x$ & 634.3 & $x$ & $x$ \\
\hline
\end{tabular}

* Trait mean values in each comparison between dehulled and pearled barley with different labels are significant at the $p<0.01$, ** CPB, commercial sample of pearled barley.

Concentration of $\beta$-glucan for dehulled barley samples varied from 40.0 to $53.0 \mathrm{~g} \cdot \mathrm{kg}-1$ an for pearled grain from 40.1 to $59.2 \mathrm{~g} \cdot \mathrm{kg}^{-1}$ (Table 2). Correlation of $\beta$-glucan between dehulled and pearled barley grain samples was high and significant $\mathrm{r}=0.910(p<0.01)$. The difference in $\beta$-glucan concentration between dehulled and pearled grain was not significant although in pearled barley $\beta$-glucan concentration was higher by $0.9 \mathrm{~g} \cdot \mathrm{kg}^{-1}$. This indicated the effect of removal of the outer kernel layers of various barley varieties by pearling on variation of $\beta$-glucan content in pearled grain product. For several accessions, such as 'Grimmet', 'Landsorte aus Tirol', and 'G-83', $\beta$-glucan concentration was higher in pearled grain, but lower for another varieties.

Concentration of $\beta$-glucan in hulless barley was higher than in most of the covered barley samples. Commercial pearled barley had $\beta$-glucan concentration $\left(47.0 \mathrm{~g} \cdot \mathrm{kg}^{-1}\right)$ above the level of this trait in pearled grain of covered barley samples.

Ash concentration among dehulled barley varied from 14.2 to $18.7 \mathrm{~g} \cdot \mathrm{kg}^{-1}$ and it was higher for genotypes characterised with comparatively higher crude protein and $\beta$-glucan concentration. As the outer layers of the grain were removed by pearling, crude ash concentration in the pearled grain significantly $\left(p<0.001\right.$ ) decreased (by $3.4 \mathrm{~g} \cdot \mathrm{kg}^{-1}$ ), and a larger difference was observed for genotypes with high $\beta$-glucan concentration in the dehulled grain product. Commercial sample of pearled barley showed crude ash concentration 
$\beta$-GLUCAN AND CRUDE ASH CONCENTRATION IN DEHULLED, PEARLED AND HULLESS BARLEY GRAIN

\begin{tabular}{|c|c|c|c|c|c|c|}
\hline \multirow{2}{*}{ Accessions } & \multicolumn{3}{|c|}{$\beta$-glucan, $\mathrm{g} \cdot \mathrm{kg}^{-1}$} & \multicolumn{3}{|c|}{ Crude ash, $\mathrm{g} \cdot \mathrm{kg}^{-1}$} \\
\hline & $\begin{array}{c}\text { dehulled } \\
\text { grain }\end{array}$ & $\begin{array}{c}\text { pearled } \\
\text { grain }\end{array}$ & $\begin{array}{c}\text { differ- } \\
\text { ence }\end{array}$ & $\begin{array}{c}\text { dehulled } \\
\text { grain }\end{array}$ & $\begin{array}{c}\text { pearled } \\
\text { grain }\end{array}$ & $\begin{array}{c}\text { differ- } \\
\text { ence }\end{array}$ \\
\hline \multicolumn{7}{|c|}{ Covered barley, processed grain } \\
\hline ST-12902 & 47.2 & 47.0 & -0.2 & 15.5 & 12.6 & -2.9 \\
\hline ST-13083 & 38.2 & 41.2 & 3.0 & 16.0 & 12.1 & -3.9 \\
\hline ST-13074 & 44.1 & 45.0 & 0.9 & 17.6 & 13.0 & -4.6 \\
\hline ST-12924 & 41.5 & 41.0 & -0.5 & 15.9 & 11.7 & -4.2 \\
\hline ST-12835 & 40.0 & 40.1 & 0.1 & 15.1 & 12.7 & -2.4 \\
\hline Quench & 41.0 & 39.0 & -2.0 & 14.6 & 12.6 & -2.0 \\
\hline Abava & 45.3 & 41.3 & -4.0 & 14.7 & 14.1 & 0.6 \\
\hline Jumara & 46.0 & 48.0 & 2.0 & 18.2 & 14.4 & -3.8 \\
\hline Ansis & 43.5 & 44.9 & 1.4 & 14.2 & 13.2 & -1.0 \\
\hline Grimmet & 46.0 & 48.0 & 2.0 & 19.6 & 14.9 & -4.7 \\
\hline $\begin{array}{l}\text { Landsorte aus } \\
\text { Tirol }\end{array}$ & 47.1 & 49.1 & 2.0 & 18.7 & 14.0 & -4.7 \\
\hline $\mathrm{G}-83$ & 53.0 & 59.2 & 6.2 & 18.6 & 13.6 & -5.0 \\
\hline Average & $44.4 a^{*}$ & $45.3 \mathrm{a}$ & 0.9 & $16.6 \mathrm{a}$ & $13.2 \mathrm{~b}$ & -3.4 \\
\hline $\mathrm{CPB}^{* *}$ & $\times$ & 47.0 & $\times$ & $\times$ & 10.3 & $\times$ \\
\hline \multicolumn{7}{|c|}{ Hulless barley, unprocessed grain } \\
\hline Irbe & 50.3 & $\times$ & $\times$ & 16.6 & $\times$ & $\times$ \\
\hline Kornelija & 58.0 & $x$ & $x$ & 19.4 & $x$ & $x$ \\
\hline
\end{tabular}

* Trait mean values in each comparison between dehulled and pearled barley with different labels are significant at the $p<0.01$, ** CPB, commercial sample of pearled barley.

$\left(10.3 \mathrm{~g} \cdot \mathrm{kg}^{-1}\right)$ lower as in the pearled grain of covered barley included in this trial.

There was rather high variation in the total phenolic $\beta$-glucan concentration among dehulled whole grain samples of covered barley, with a range from $166.8 \mathrm{mg}$ GAE $100 \mathrm{~g}^{-1} \mathrm{DW}$ for barley variety 'Abava' to $212.2 \mathrm{mg}$ GAE $100 \mathrm{~g}^{-1}$ DW for barley genotype 'G-83' with black colour grain (Table 3). Pearling resulted in a significant decrease of phenolic $\beta$-glucan concentration in the pearled grain product (on average by $52.4 \mathrm{mg}$ GAE $100 \mathrm{~g}^{-1} \mathrm{DW}$ or by $29 \%$ ), compared to dehulled or whole grain of covered barley. The phenolic concentration in the whole grain of covered barley samples was 1.30 to 1.61 times higher than for pearled grains. Higher total phenolic concentration in dehulled grain was found also in the breeding line 'ST-13074' (204.1 mg GAE $100 \mathrm{~g}^{-1}$ ), and also in respective pearled grains (144.9 mg GAE $100 \mathrm{~g}^{-1}$ ).

As the outer layers of the grain were removed by pearling, average radical scavenging activity in the pearled grain was significantly ( $p<0.001$ ) lower (by 34\%), compared to that in the dehulled grain fraction; a larger difference was observed for genotypes with high radical scavenging activity in the dehulled grain fraction. Total phenolic concentration and their activity in grains of both hulless barley genotypes were higher than in covered barley. The commercial sample of pearled barley had lower total phenolic concentration and
TOTAL PHENOLIC CONCENTRATION AND RADICAL SCAVENGING ACTIVITY IN DEHULLED, PEARLED AND HULLESS BARLEY GRAIN

\begin{tabular}{l|c|c|cc}
\hline \multirow{2}{*}{ Accessions } & \multicolumn{2}{c|}{$\begin{array}{c}\text { Total phenolic concentration, } \\
\text { mg GAE 100 g }{ }^{-1} \text { DW }\end{array}$} & \multicolumn{2}{c}{$\begin{array}{c}\text { Radical scavenging } \\
\text { activity, \% }\end{array}$} \\
\cline { 2 - 5 } & dehulled grain & pearled grain & dehulled grain & pearled grain \\
\hline \multicolumn{5}{c}{ Covered barley, processed grain } \\
ST-12902 & $190.6 \pm 12.6$ & $135.4 \pm 2.8$ & $74.2 \pm 1.5$ & $46.1 \pm 0.3$ \\
ST-13083 & $168.80 \pm 4.1$ & $141.5 \pm 2.6$ & $66.9 \pm 0.7$ & $41.2 \pm 1.4$ \\
ST-13074 & $204.1 \pm 1.7$ & $144.9 \pm 2.5$ & $73.7 \pm 2.3$ & $40.1 \pm 0.7$ \\
ST-12924 & $190.9 \pm 1.3$ & $131.7 \pm 2.9$ & $61.7 \pm 0.7$ & $37.8 \pm 0.8$ \\
ST-12835 & $171.8 \pm 8.6$ & $135.4 \pm 2.8$ & $61.0 \pm 6.5$ & $41.2 \pm 0.5$ \\
Quench & $182.6 \pm 10.3$ & $135.2 \pm 2.8$ & $69.0 \pm 1.7$ & $40.6 \pm 1.3$ \\
Abava & $166.8 \pm 8.5$ & $120.4 \pm 3.7$ & $69.1 \pm 2.0$ & $43.8 \pm 2.3$ \\
Jumara & $182.0 \pm 8.5$ & $131.6 \pm 2.9$ & $70.2 \pm 1.6$ & $47.2 \pm 1.3$ \\
Ansis & $168.8 \pm 7.8$ & $104.8 \pm 3.6$ & $63.7 \pm 3.6$ & $37.4 \pm 0.2$ \\
Grimmet & $188.3 \pm 7.3$ & $136.9 \pm 7.7$ & $70.1 \pm 9.5$ & $37.7 \pm 0.8$ \\
Landsorte aus & $195.4 \pm 7.0$ & $129.9 \pm 5.5$ & $62.7 \pm 3.2$ & $41.2 \pm 1.6$ \\
Tirol & \multicolumn{5}{c}{} & \\
G - 83 & $212.2 \pm 5.1$ & $146.0 \pm 8.8$ & $73.5 \pm 6.5$ & $50.1 \pm 4.5$ \\
Average & $\mathbf{1 8 5 . 2 a *}$ & $\mathbf{1 3 2 . 8 b}$ & $\mathbf{6 8 . 0 a}$ & $\mathbf{4 2 . 0 b}$ \\
CPB** & $\times$ & $121.5 \pm 9.5$ & $\times$ & $39.9 \pm 3.6$ \\
& Hulless barley, unprocessed grain & \\
Irbe & $208.2 \pm 4.9$ & $\times$ & $79.5 \pm 3.9$ & $\times$ \\
Kornelija & $198.9 \pm 10.0$ & $\times$ & $74.7 \pm 0.3$ & $\times$ \\
& & & &
\end{tabular}

* Trait mean values $(\mathrm{n}=3)$ in each comparison between dehulled and pearled barley with different labels are significant at the $p<0.01$; ** Commercial sample of pearled barley.

radical scavenging activity than in dehulled and pearled fractions. There were no significant relationships in total phenolic concentration and their activity between dehulled and pearled grain.

\section{DISCUSSION}

Covered barley grain is comprised of the hull, pericarp, testa, aleurone, endosperm and embryo (Newman and Newman, 2008). In this study, a short pearling time of 0.33 min was used to produce dehulled grains from covered barley, resulting in whole grain or unprocessed hulless barley. As a result about $12 \%$ by weight of the covered original kernel was removed, mainly consisting of the hull and some of the other layers. About $70 \%$ pearled grain was obtained by pearling the grain of covered barley for $1.4 \mathrm{~min}$. The resulting fines amounted to about $30 \%$ of the original kernel weight and contained much of the pericarp, testa, and aleurone layers together with some of the embryo and endosperm. In a two-row covered barley kernel, the approximate proportions of different components of barley grain are $10-13 \%$ hull, $2-3 \%$ pericarp and testa, $4-5 \%$ aleurone, $77-82 \%$ endosperm, and $2-3 \%$ embryo on a DM basis (Baik and Ullrich, 2008). The study showed significant differences in concentration of crude protein and starch among grain samples of various genotypes differently processed by 
pearling. As the outer layers of the covered grain were removed by pearling, crude protein concentration in the pearled grain decreased significantly, and the starch concentration increased. Crude protein concentration decreases and starch concentration increases from the outer fractions to the inner grain (Sumner et al., 1985; Klamczynski et al., 1998; Liu et al., 2009). Pearling process removes most of the aleurone layer, which has higher protein concentration (Jadhav et al., 1998; Sullivan et al., 2010; van Donkelaar et al., 2015). The embryo tissue, which usually is partly removed during pearling, is rich in protein (more $30 \%$ of the grain) (Shewry, 2014).

Among cereals, the highest concentrations of $\beta$-glucans are found in barley and oat grains (Havrlentova et al., 2011). Unlike oats, in which most of the $\beta$-glucans are concentrated more in the outer portion of kernel, in barley $\beta$-glucans are found in the aleurone, subaleirone and throughout the starchy endosperm (Baik, 2014). This can explain why pearling of $30 \%$ of the grain had little effect on $\beta$-glucan concentration. In some of the analysed barley varieties, $\beta$-glucan concentration increased in the pearled product. Similar observations were reported by Liu et al. (2009). In the study of Klamczynski et al. (1998) in $40 \%$ pearled kernels of covered barley, $\beta$-glucan concentration increased by $12 \mathrm{~g} \cdot \mathrm{kg}^{-1}$ compared to nonpearled kernels, an reached a peak at about $60 \%$ surface removal (van Donkelaar et al., 2015). In a study with hulless barley, $\beta$-glucan concentration was observed to increase also from external to the internal layers of grain (Blandino et al., 2015b). As cell wall material is one of the three main structures in barley endosperm, in addition to the protein matrix and starch granules, a relatively high level of $\beta$-glucan in endosperm is expected (Jadhav et al., 1998).

As the outer layers of the grain were removed by pearling, crude ash concentration in the pearled grain significantly decreased. Our results agreed with data reported also in other studies (Blandino et al., 2015b; Klamczynski et al., 1998; van Donkelaar et al., 2015). Concentration of all minerals are decreased by pearling, mineral content is larger in the bran and germ (Shewry, 2014).

Among cereals, barley can be a good source of phenolic compounds that are bound to cell walls and mainly can be found in the bran and germ fraction, and thus whole barley flours provide greater overall physiological effects and higher health benefits (Dykes and Rooney, 2007). Metabolites like phenolic compounds possess antiradical and antioxidant activity (Ragaee et al., 2006) and play a preventive role in the development of cancer, heart and age related diseases (Halliwell, 2007). Our results indicated that grain pearling reduced both total phenolic concentration and antiradical scavenging activity decreased significantly $(p<$ 0.001 ), as the concentrations decrease from the external to the internal parts of grain. The highest phenolic concentration was observed in the outermost fraction (Madhujith et al., 2006). Similar observations were reported also in a study on hulless barley, where the total antioxidant activity was higher in the $15-25 \%$ pearling fractions (Blandino et al., 2015a). Therefore, pearling makes it possible to obtain barley fractions with different amounts of phenolics, and thus different antioxidant activities (Holtekjolen et al., 2011).

In the present study there was considerable variation among barley samples in all analysed chemical traits for the dehulled (or whole) grain, pearled grain of covered barley, and also hulless barley. These differences in chemical composition of barley varieties may be explained by genetic variation, since the varieties were grown under the same environmental conditions. These differences in chemical composition can be considered when selecting a barley variety as raw material for pearling and nutritional quality of end product. According to Nair et al. (2011b), kernel loss due to pearling was $28.8-38.4 \%$ and showed significant negative correlation with grain hardness index, which is a resultative trait of the complex interaction between compositional and structural endosperm components (Nair et al., 2011a).

Unprocessed hulless barley has higher crude protein, $\beta$-glucan, total phenolic concentration and radical scavenging activity in the whole grain, than in covered barley genotypes. The covered genotype ' $G-83$ ' with blue seed coat had higher crude protein, $\beta$-glucan, and total phenolic concentration and their radical antiscavenging activity in both dehulled and pearled grain fractions. Barley varieties can be modified further by selection on the basis of appropriate pearling quality and improved chemical composition providing functional properties of whole grain and pearled product. Our results showed that covered barley after minimal processing and hulless barley could both be considered as whole grain barley, and both make good choices from a nutritional standpoint.

The results of the present study confirmed that barley pearling is a refining process, as it removes protein, soluble fibre and minerals, and other biologically active compounds like phenolics and their associated activity. Pearling produces rather high amounts of the waste fraction and deteriorates the nutritional value of the resulting barley flour. Additional research is required to evaluate the properties of different barley fractions including also analysis of outer kernel layers or fines produced by pearling, in relation to the used genetic diversity. Preservation of beneficial components by optimising the pearling degree could be an important issue as well.

\section{ACKNOWLEDGEMENTS}

This research was supported by National Research Programme AgroBioRes project "Sustainable use of local agricultural resources for qualitative and healthy food product development" (FOOD) No 10-4/VPP-7/3.

\section{REFERENCES}

Ames, N. P., Rhymer, C. R. (2008). Issues surrounding health claims for barley. J. Nutr., 138 (6), 1237-1243. 
Anonymous (2006). Setting maximum levels for certain contaminants in foodstuffs. European Commission Regulation No. 1881/2006. OJ EU, 19 December 2006, L364, 5-24.Baik, B. K, Ullrich, S. E. (2008). Barley for food: Characteristics, improvement, and renewed interest. J. Cereal Sci., 48, 233-242.

Baik, B. K. (2014). Processing of barley grain for food and feed. In: Shewry, P. R., Ullrich, S. E. (Ed.). Barley: Chemistry and Technology. AACC International, St. Paul, pp. 233-268.

Blandino, M., Locatelli, M., Sovrani, V., Coḷsson, J. D., Rolle, L., Travaglia, F., Giacosa, S., Bordiga, M., Scarpino, V., Reyneri, A., Arlorio, M. (2015a). Progressive pearling of barley kernel: Chemical characterization of pearling fractions and effect of their inclusion on the nutritional and technological properties of wheat bread. J. Agric Food Chem., 63 (25), 5875-5884.

Blandino, M., Locatelli, M., Gazzola, A., Coḷsson, J. D., Giacosa, S., Travaglia, F., Bordiga, M., Reyneri, A., Rolle, L., Arlorio, M. (2015b). Hull-less barley pearling fractions: Nutritional properties and their effect on the functional and technological quality in bread-making. J. Cereal Sci., 65 (1), 48-56.

Bleidere, M., Grunte, I. (2008). Grain chemical compositions of spring barley genotypes. In: Research for Rural Development 2008: Proceedings of 14th International Scientific Conference, 21-23 May 2008, Jelgava. Latvia University of Agriculture, Jelgava, pp. 334-340.

Donkelaar van, L. H. G, Noordman, T. R., Boom, R. M., van der Goot, A. J. (2015). Pearling barley to alter the composition of the raw material before brewing. J. Food Eng., 150, 44-49.

Dykes, L., Rooney, L. W. (2007). Phenolic compounds in cereal grains and their health benefits. Cereal Food World, 52, 105-111.

Halliwell, B. (2007). Dietary polyphenols: Good, bad, or indifferent for our health? Cardiovasc. Res., 73, 341-347.

Havrlentova, M., Petrulakova, Z., Burgarova, A., Gago, F., Hlinkpova, A., Sturdik, E. (2011). Cereal $\beta$-glucans and their significance for the preparation of functional foods: Reviw. Czech J. Food Sci., 29 (1), 1-14.

Holtekjolen, A. K., Sahlstrom, S., Knutsen, S. H. (2011). Phenolic content and antioxidant activities in covered whole-grain flours of Norwegian barley varieties and in fractions obtained after pearling. Acta. Agric. Scand., 61, 67-74.

Received 10 November 2016

Accepted in the final form 6 December 2017
Izydorczyk, M. S., Dexter J. E. (2008). Barley $\beta$-glucans and arabinoxylans: Molecular structure, physicochemical properties, and uses in food products: Review. Food Res. Int., 41, 850-868.

Jadhav, S., Lutz, S., Ghorpade, V., Salunkhe, D. (1998). Barley: Chemistry and value added processing. Crit. Rev. Food Sci., 38 (2), 123-171.

Klamczynski, A, Baik, B. K., Czuchajowska, Z. (1998). Composition, microstructure, water imbibition, and thermal properties of abraded barley. Cereal Chem., 75, 677-685.

Liu, K., Barrows, F. T., Obert, D. (2009). Dry fractionation methods to produce barley meals varying in protein, beta-glucan, and starch contents. $J$. Food Sci., 74 (6), 487-499.

Madhujith, T., Izydorczyk, M., Shahidi, F. (2006). Antioxidant properties of pearled barley fractions. J. Agric. Food Chem. 54 (9), 3283-3289.

Nair, S., Knoblauch, M., Ullich, S., Baik, B. K. (2011a). Microstructure of hard and soft kernels of barley. J. Cereal Sci., 54 (3), 354-362.

Nair, S., Ullrich S. E., Baik, B. K. (2011b). Association of barley kernel hardness with physical grain traits and food processing parameters. Cereal Chem., 88 (2), 147-152.

Newman, R. K., Newman, C. W. (eds.) (2008). Barley for Food and Health Science, Technology, and Products. A John Willey \& Son, Inc., USA. $245 \mathrm{pp}$.

Ragaee, S., Abdel-Aal, E.-S. M., Noaman, M. (2006). Antioxidant activity and nutrient composition of selected cereals for food use. Food Chem., 98 (1), 32-38.

Sharma, P., Kotari, S. L. (2016). Barley: Impact of processing on physicochemical and thermal properties: Review. Food Rev. Int., 1-23.

Sullivan, P., O'Flaherty, J., Brunton, N., Gee, V. L., Arendt, E., Gallagher, E. (2010). Chemical composition and microstructure of milled barley fractions. Eur. Food Res. Technol., 230 (4), 579-595.

Sumner, A., Grebre-Egziabher, A., Tyler, R., Rossnagel, B. (1985). Composition and properties of pearled and fines fractions from hulled and hull-less barley. Cereal Chem., 62 (2), 112-116.

Shewry, P. R. (2014). Minor components of the barley grain: Minerals, lipids, terpenoids, phenolics, and vitamins. In: Shewry, P. R, Ullrich, S.E. (eds.). Barley: Chemistry and Technology. AACC International, St. Paul, pp. 169-192.

\section{VASARAS MIEŽU GRAUDU BIOĶĪMISKAIS SASTĀVS ATKARĪBĀ NO GRAUDU APSTRĀDES PAKĀPES}

Pētījuma mērḳis bija salīdzināt bioḳīmisko savienojumu daudzumu vasaras miežu (Hordeum vulgare L.) paraugos ar atšḳirīgu graudu apstrādes pakāpi. Analizēja 12 plēkšn,graudu, divu kailgraudu miežu genotipu un komerciālo skrotēto miežu (grūbu) paraugus. Plēkšṇgraudu miežus apstrādāja ar laboratorijas skrotētāju, lai iegūtu atplēkšṇoto jeb pilngraudu un skrotēto miežu graudu paraugus, mehāniski noberžot attiecīgi $12 \%$ un $30 \%$ no graudu ārējā apvalka. Rezultāti parāda, ka plēkšngraudu miežiem ir būtiskas $(p<0.001)$ bioḳīmiskā sastāva atšḳirības atplēkšņoto un skrotēto miežu paraugos. Miežu paraugos ar augstāku grauda ārējā apvalka apstrādes pakāpi, būtiski samazinās kopproteīna un koppelnu saturs, fenolsavienojumi un to aktivitāte, būtiski pieaug cietes saturs, bet $\beta$-glikānu daudzums būtiski nemainās. Fenolsavienojumu daudzums pilngraudu paraugos bija 1.3 līdz 1.6 reizes augstāks nekā skrotēto miežu graudu paraugos. Salīdzinot biokīimiskā sastāva atškirīibas starp dažādu genotipu pilngraudu un skrotēto graudu paraugiem, būtiskas un ciešas korelatīvās sakarības $(p<0.01)$ konstatēja pēc koproteīna, cietes un beta-glikānu satura, ko nenovēroja kopējo fenolsavienojumu saturam un to aktivitātei. 